\title{
CONFERÊNCIA
}

\section{O animal e o primitivo: os outros de nossa cultura ${ }^{1}$}

The animal and primitives: Other aspects o four culture

Benedito Nunes - Paraense, professor emérito da Universidade Federal do Pará, filósofo, crítico literário e escritor premiado com o "Jabuti" e o "Machado de Assis", falecido em 27 de fevereiro de 2011.

Dado que as raízes de nossa cultura são greco-latinas, há que destacar a presença desses que ficam à margem dela, o animal e o primitivo. A noção que me parece ser um elemento de ligação entre ambos é a de 'bárbaro', tal como os gregos a usavam: aquele considerado estranho à cultura grega ou à sua área de influência, estranho que normalmente era considerado também adversário; o diferente se tornava o oposto, e o oposto se tornava inimigo. Na nossa cultura encontramos essa relação entre diferente e oposto, diferente e inimigo, no nexo havido entre nós e esses outros, entre nós e o animal, ou entre nós e os primitivos.

Com o animal, as relações são, sobretudo, transversais, ou seja, o animal é considerado o oposto do homem mas ao mesmo tempo uma espécie de simbolização do próprio homem. Na acepção comum, simboliza o que o homem teria de mais baixo, de mais instintivo, de mais rústico ou rude na sua existência. Por isso mesmo o animal para nós é o grande outro da nossa cultura, e essa relação é muito interessante como tópico de reflexão.

Sob a dominância do cristianismo, os deuses antigos, pagãos, foram demonizados ou revoaram para o interior adusto, não urbanizado, ou ainda para o mais fundo da alma. Passamos então a ver o animal simbolizando o irascível dos sentimentos e a bruteza dos instintos. O animal habitava o homem e dentro dele rugia, porém como algo que lhe fosse estranho.

1 Conferência proferida em 21 de outubro de 2005 no seminário "Saúde, Meio Ambiente e Cultura: 100 Anos de Oswaldo Cruz na Amazônia”, realizada em Manaus, e depois editada em dezembro de 2007 na revista "História, Ciências , Saúde - Manguinhos" - publicação da Casa de Oswaldo Cruz / Fundação Oswaldo Cruz -, Rio de Janeiro, v. 14, suplemento, p. 279-290, com apresentação de Jaime Larry Benchimol. Agradecemos a autorização para sua republicação no espaço de Novos Cadernos $N A E A$. 
Quando o darwinismo colocou-nos no topo da evolução, abrindo-nos a segunda ferida narcísica, depois daquela que Copérnico nos infringira, o pensamento filosófico moderno já havia separado o homem do animal. Homem e animal se tornariam cada vez mais estranhos entre si quanto mais se consolidasse, a partir do século XVII, na filosofia cartesiana, a identidade entre pensamento e consciência. Com efeito, Descartes efetuaria, depois da demonização cristã do animal, o primeiro corte moderno entre este e o homem, aproximados na Antiguidade por meio da noção de alma, tanto em Platão quanto em Aristóteles, que reconhecia uma alma sensitiva, uma alma racional e uma alma vegetativa.

Para Descartes o homem é o animal racional, tendo na sua razão ou na linguagem a diferença que o distingue da animalidade. Mas o ser do homem coincide, de acordo com o ponto de vista cartesiano, que é o ponto de vista moderno, com a evidência do pensar. O animal é o que de mais estranho a nós se torna. É o grande Outro porque é um corpo sem alma, um simples mecanismo. Essa é a teoria mecanicista de Descartes que prevaleceu nos séculos XVII e XVIII.

Hegel, já no começo do século XIX, daria o segundo corte na relação de que estamos tratando, ao recuperar a consciência como espírito ou Geist. Dali por diante, o animal, no homem, só poderia ser o bas-fond do espírito, o objeto digno de uma zoologia demoníaca que assombraria, naquele século, o santo Antônio de Flaubert com visões lúbricas e animalescas. (mais tarde ela daria lugar à zoologia fantástica de Jorge Luis Borges.)

Um dos mais nobres esforços da ala heterodoxa da filosofia moderna, de Schopenhauer até hoje, secundada pela poesia lato sensu, é aquela que tende a reconquistar a proximidade perdida desde a Antiguidade entre homem e animal. Ambos sofrem, ambos estão sujeitos à dor - este é o ponto principal. E embora um filósofo como Heidegger nos diga que o animal, ao contrário do homem, é pobre de mundo (Weltarm) por mais que seja rico de ambiente, continuamos ouvindo a réplica que lhe dá o grande pensamento poético de Rainer Maria Rilke. O animal vive no seio da natureza - como diz na sua "Oitava elegia", em Elegias de Duíno"enquanto nós os trepidantes sofremos do mundo que nos punge e empobrece". Quer dizer, colhido no ventre da mãe natura, o animal vê os homens com aquele olhar não-humano que a ficção de uma das melhores autoras da nossa literatura, Clarice Lispector, insuperavelmente descreveu no conto "O búfalo", de Laços de família: aí o olhar animal é um olhar que tem conexão com os sentimentos mais violentos do homem. 
O animal continua sendo o grande Outro, o maior alienado da nossa cultura, "exceto que essa cultura, aumentando o nosso conhecimento, talvez possa algum dia restabelecer os estreitos laços que a ele nos unia nos tempos mitológicos, mas quando isso acontecer - comenta Elias Canetti - já quase não mais haverá animais entre nós".

O que se defende aqui é um companheirismo entre homem e animal, como nas páginas que vêm de John Maxwell Coetzee, autor sul-africano detentor do prêmio Nobel alguns anos atrás. Refiro-me a uma espécie de ficção de caráter ensaístico de sua autoria, em que se discute a conferência de uma senhora defensora dos direitos dos animais. A conferência é comentada por autores reais pró e contra animais, que escrevem como naturalistas, em apêndices no livro. Do texto de Coetzee (Elizabeth Costello) destaco o seguinte trecho:

As pessoas reclamam que tratamos os animais como objetos, mas na verdade tratamos os animais como prisioneiros de guerra. Você sabia (diz um personagem ao outro) que quando foram abertos os primeiros zoológicos, os tratadores tinham que proteger os animais dos ataques dos espectadores. Os espectadores sentiam que os animais estavam ali para serem insultados e humilhados, como prisioneiros em uma marcha triunfal. Já promovemos uma guerra contra os animais, que chamamos de caça, embora, na verdade, guerra e caça sejam a mesma coisa, Aristóteles percebeu isso claramente. Essa guerra foi travada ao longo de milhões de anos, só a vencemos definitivamente faz algumas centenas de anos, quando inventamos as armas de fogo. Só quando a vitória foi absoluta é que pudemos nos permitir cultivar a compaixão, mas a nossa compaixão é muito rarefeita. Por baixo dela existe uma atitude mais primitiva, o prisioneiro de guerra não pertence à nossa tribo, podemos fazer o que quisermos com ele, podemos sacrificá-lo aos nossos deuses, podemos cortar seu pescoço, arrancar seu coração, atirá-lo no fogo. Não existe lei quando se fala de prisioneiro de guerra.

Em geral não se matam os prisioneiros de guerra, que são feitos escravos. Nossos rebanhos são populações escravas. O trabalho deles é se reproduzirem para nós. Até seu sexo transforma-se em uma forma de trabalho. Não os odiamos mais porque nem sequer são dignos do nosso ódio. Nós os vemos com desprezo. Mas ainda existem animais que odiamos, como os ratos, que não se renderam. Eles reagem, se organizam em unidades subterrâneas em nossos esgotos. Não estão vencendo, mas também não estão perdendo. Sem falar dos insetos e micróbios, que podem nos vencer e certamente sobreviverão a nós. 
É interessante observarmos que, ultimamente, a preocupação com o animal vem se transformando na 'questão' do animal. Para muitos de uma maneira um tanto exacerbada, como é caso de Peter Singer quando nos fala do preconceito denominado 'especismo', que nos move. Quer dizer, nossa espécie é única, ela é predominante. Por isso mesmo Peter Singer fala de uma libertação animal. O que significa isso? A libertação dos animais em relação à submissão aos homens, que os prendem há séculos. Mas, a meu ver, não se trata disso.

Entre os autores que viram bem essa questão destaca-se o inglês Jeremias Bentham, do século XVIII. Ele mostrou que não se trata de libertar o animal da submissão ao homem, mas de uma libertação do sofrimento. Os animais sentem dor, os animais sofrem, têm um sistema nervoso com terminações que são portadoras de estímulo doloroso, daí a necessidade de falar dessa libertação. Trata-se então da libertação da dor e também da libertação da crueldade. Essa questão foi focalizada principalmente por um autor de quem não se esperava, o filósofo Arthur Schopenhauer.

Schopenhauer faz alusões ferinas a respeito do tema. Nenhum animal maltrata apenas por maltratar, mas o homem sim, e nisso constitui o seu caráter demoníaco, muito mais grave do que o caráter simplesmente animal. Qualquer um tem a oportunidade de observá-lo na caça e, sobretudo, no exercício da crueldade. Alguém chamou o homem de "animal mau por excelência", por isso todos os demais temem instintivamente à vista dele ou ao seu rastro. Esse instinto não se engana, porque o homem também vai à caça de animais que não lhe são úteis nem prejudiciais. Da maldade humana e seus aspectos mais amplos falamos mais acima... Nesse mesmo tópico insere-se a observação de Jeremias Bentham: "Eu não posso saber se os animais têm inteligência, se os animais têm alma, mas posso saber se os animais sofrem. Isso é o essencial da questão”.

Há toda uma história sob essa perspectiva que agora é reconstruída por Peter Singer, sobretudo a do relacionamento do animal com o homem, devido à menor ascendência, atualmente, do relato bíblico acerca da origem do homem. Do ponto de vista bíblico os animais teriam sido feitos para o homem utilizar. À medida que entra em cena a teoria da evolução, a história é pensada diferentemente e nós tivemos que pensar no homem como animal. E esse pensamento do homem como animal é que nos traz problemas como aqueles a que se refere Peter Singer, quando fala da libertação animal. 
O sofrimento que infligimos a eles, os seres não-humanos, pode ser extremo, e o número de indivíduos implicados é gigantesco. Nos Estados Unidos, cem milhões de porcos, bois e carneiros são sacrificados a cada ano, e milhares de aves também. Pelo menos 25 milhões de animais sofrem experiências em laboratórios. A solução proposta por Peter Singer é o vegetarianismo. (No que me diz respeito, é tarde para ser vegetariano; eu teria que aprender um novo sistema de vida, e na idade em que estou não é o caso de fazê-lo.)

Leiamos, ainda, este trecho de Peter Singer em Libertação animal:

Nós consideramos os leões e os lobos como selvagens porque eles matam, mas ou eles matam ou eles morrem de fome. Os humanos matam outros animais por esporte, para satisfazer a sua curiosidade, para embelezar o corpo e para agradar o paladar. Os seres humanos matam, além disso, membros da sua própria espécie, por cupidez e por desejo de poder. (...) Além do mais, os seres humanos não se contentam simplesmente em matar, além disso, através de toda a história, eles mostraram uma tendência para atormentar e torturar tanto seus semelhantes humanos como seus semelhantes animais, antes de fazê-los morrer. Nenhum animal se interessa muito por isso, isto é, pela tortura.

O segundo Outro da nossa cultura é o primitivo (o índio, o selvagem), que chegou a gerar uma questão teológica, dirigida sob forma de consulta ao papa: os índios têm alma? Na mesma época, na sociedade brasileira, começava a aparecer o negro como instrumento de trabalho. Os índios fugiam ao trabalho, mas adotavam a religião dos senhores que lhes era incutida por meio da catequese, que entretanto também teve seus paradoxos. Assim é que o motivo de maior estranhamento dos que vinham de fora, os portugueses e os jesuítas da catequese, era a antropofagia entre os índios. E não os afligia de modo nenhum o comportamento religioso dos escravos, que praticavam interessantíssimo sincretismo religioso. Aliás, 'sincretismo' talvez não seja a noção adequada, já que as divindades originárias da cultura religiosa dos negros escravos, os orixás, eram ocultadas por santos católicos que mantinham com estes certas semelhanças. Mas não havia ocultamento do canibalismo. Todos os depoimentos que temos, os escritos da época da descoberta, todos os documentos mostram que o canibalismo era uma antropofagia. Existe o canibalismo que não é antropofágico como, por exemplo, a ingestão de partes pequenas, como unhas e pedaços de dedos dos mortos. A absorção da carne humana, da carne do outro, morto em batalha, era antropofagia, a ingestão do 
inimigo chamado 'sagrado', inimigo sacro, aquele que tinha virtudes a serem aproveitadas. A ingestão de carne humana era, então, ao mesmo tempo um ato de vingança e de apropriação das faculdades do inimigo corajoso. Essa ingestão proporcionava, portanto, uma continuidade mágica do espólio consumido.

Um outro paradoxo da catequese é o aldeamento, quer dizer, a formação de grandes concentrações indígenas como a grande redução do Paraguai, por exemplo, que juntavam índios sob a dominação dos jesuítas. Conta-se que na redução das Missões, até as horas prescritas para as refeições, para o relacionamento entre marido e mulher, tudo estava prescrito e ao mesmo tempo anunciado por badaladas do sino da igreja principal.

A questão não só do índio como do negro em nossa cultura se coloca sob dois focos. Um foco mais antigo era considerar que esses 'primitivos' tinham uma mentalidade diferente da nossa, chamada 'pré-lógica', não lógica porque antecede a lógica. Isso foi defendido pelo etnólogo francês Lucien Lévy-Bruhl em seu livro A mentalidade primitiva, muito conhecido. O segundo foco defendia que o primitivo, principalmente o índio e o negro, estavam ligados à natureza e dela participavam. Tal participação era ao mesmo tempo arrimada às coisas e conduzida por potências místicas. Este era o ponto de vista de Lévy-Bruhl.

O grande avanço da antropologia, obtido principalmente com a abordagem estrutural de Lévi-Strauss, foi ter revisto essa condição pré-lógica do pensamento primitivo. Para o antropólogo não há um pensamento selvagem se não no sentido de que tal pensamento, articulando-se pelas mesmas leis lógicas que nos conduzem, não é regido pelo principio de utilidade. Nesse sentido podemos até relacionar o pensamento mágico à ciência, se considerarmos as grandes descobertas do neolítico - é impossível separarmos dessa primitividade as descobertas agrícolas, o tratamento da terra etc.

Melhor seria, então, admitir dois modos de ciência: aquele que está mais próximo do real, por intermédio da imaginação; e outro que está um pouco mais distante do real, pelo raciocínio, pelos conceitos abstratos. Os dois modos de ciência se complementam e não podemos deixar de admiti-los, um mais próximo da realidade imediata apreendida pelos sentidos e outro mais distante, conduzido pelo pensamento e pelos conceitos.

Lévi-Strauss, em Tristes trópicos - uma obra notável, misto de antropologia, boa literatura e reflexão filosófica, orientada para o conhecimento da natureza e dos primitivos - fala-nos da adesão do primitivo ao mundo físico, uma adesão que 
é feita por intermédio dos sentidos. Assim, por exemplo, quase todas as aldeias, principalmente as bororos, têm uma forma circular, propícia ao relacionamento dos habitantes da aldeia. As relações das duas metades do círculo se regem de uma maneira singular. Os membros de uma metade só podem casar com os da outra metade, assim gerando relações de parentesco muito peculiares. Pois bem, quando os missionários salesianos iniciaram o processo de catequese nessas aldeias, eles não tiveram êxito. Mas se revelaram antropólogos muito hábeis e, percebendo que a circularidade na construção daquelas aldeias era integrante da vida dos índios, resolveram dar a estes uma outra orientação de espaço. Desfizeram então a formação circular e a catequese teve sucesso.

Outra lição, entretanto, que nos traz Tristes trópicos e me parece válida até os dias de hoje, aplica-se tanto às sociedades primitivas como a qualquer outra sociedade. Ela desponta neste trecho:

Nenhuma sociedade é perfeita, todas comportam, por natureza, uma impureza incompatível com as normas que proclamam e que se traduz concretamente por uma certa dose de justiça, de insensibilidade e de crueldade. Como avaliar essa dose? A pesquisa etnográfica consegue. Porque se é verdade que a comparação de um pequeno número de sociedades as faz parecer muito diferentes entre si, essas diferenças se atenuam quando o campo de investigação se alarga. Descobre-se então que nenhuma sociedade é essencialmente boa, mas nenhuma é absolutamente má. Todas apresentam algumas vantagens aos seus membros, a despeito de um resíduo de iniqüidade cuja importância parece aproximadamente constante e que corresponde, talvez, a uma inércia específica que se opõe, no plano da vida social, aos esforços de organização.

Para terminar, volto ao tema do animal, agora de um outro ponto de vista, aquele que nos revela uma rara e quase tresloucada adesão à vida animal, proposta numa carta imaginária de Hugo von Hofmannsthal, endereçada a lorde Bacon por Lord Chandos, pedindo-lhe desculpas por há muito tempo ter silenciado - ele que era considerado um literato tão promissor, um autor elogiado pelos eruditos etc. Lord Chandos explica nessa carta o motivo de seu afastamento, que o teria levado a uma estranha adesão à vida animal, contemplada como algo ao mesmo tempo íntimo e estranho ao homem. Eis um trecho da carta:

Desde então levo uma existência tão privada de pensamento, que mal se distingue da dos meus vizinhos, parentes e da maioria dos nobres proprietários de terra desse reino, e que não é toda desprovida de momentos exultantes e vívidos. 
Não é fácil, para mim, explicar-vos em que consistem esses bons momentos, as palavras abandonam-me de novo. Então é algo inteiramente inominado e também mal denominável, o que em tais momentos qualquer manifestação de miniambiência diária, a mim se anuncia como maré da mais alta vida enchendo um vaso. Há pouco encarreguei um dos meus rendeiros de espalhar veneno na adega do leite; de tarde saí para cavalgar, e como vós podeis supor, não mais pensei no assunto. Porém quando caminhava, nada vendo de mau em torno de mim, se não as codornizes abatidas e à distância, no campo ondulado, o grande sol náufrago, entrou-me no íntimo de repente essa adega agitada com a agonia dessa população de ratazanas. Tudo estava em mim: o ar úmido da adega, um cheiro adocicado e cortante de veneno e o ressoar dos gritos de agonia nas paredes bolorentas, os espasmos de impotência misturados ao desespero, a alucinada procura de uma saída, o gélido olhar de raiva quando duas ratazanas tentavam entrar juntas numa obstruída fenda. Mas eis-me de novo tentando as palavras que abjurei. Terá meu amigo esquecido a maravilhosa descrição em Tito Lívio das horas que precederam a destruição de Alba Longa? Como erravam pelas ruas que não mais deveriam rever, como se despediam das pedras do chão. Digo-vos, meu amigo, que tanto quanto Cartago incendiada trazia isso dentro de mim; porém, aquilo que era mais, era divino e animalesco, era o presente, o pleno e sublime presente. Ali uma mãe tinha seus filhos moribundos palpitantes em torno de si, e que nem olhava para os mortos e para os implacáveis muros de pedra, mas que para o vazio ou através do ar, olhava para o infinito, rilhando os dentes. Se um escravo serviçal arrepiouse de impotência diante da entorpecida Niobe, ele deve ter experimentado o que experimentei quando em mim a alma desse animal arreganhou os dentes contra o monstruoso destino. Desculpai-me essa descrição... (tradução minha).

E desculpai-me, também vós todos, por esse quadro de horror.

Obrigado. 